\title{
Effect of sowing dates on quinoa grains and its chemical composition
}

\author{
Shams, A.S. ${ }^{1}$ and Wafaa K. Galal ${ }^{2}$ \\ ${ }^{1}$ Crop Intensification Research Department, Field Crops Research Institute, \\ Agricultural Research Center, Giza, Egypt. \\ ${ }^{2}$ Crop Technology Research Departments, Food Technology Research Institute, \\ Agricultural Research Center, Giza, Egypt.
}

\begin{abstract}
Growing field crops under harsh conditions of arid environment in sandy soils is one of the biggest challenge facing food security especially for small-scale holdings. Quinoa(Chenopodium quinoaWilld.), the newly introduced food crop can replenish part of food gap, since; the crop is drought-salinity tolerant and can grow in sandy soil of arid and semi-arid regions and with other most harmful abiotic adverse factors that affect crop production. Field trial was carried out in Ismailia Agricultural Research Station, Agricultural Research Center,Egypt during 2010/2011 and 2011/2012 winter seasons to study the response of Quinoa CV Titicaca to three sowing dates i.e., $15^{\text {th }}$ of November, $1^{\text {st }}$ of December and $15^{\text {th }}$ of December under sandy soil using sprinkler irrigation system.

Results revealed that sowing quinoa on $15^{\text {th }}$ of December resulted in maximum plant height of 57.73 and $61.50 \mathrm{~cm}$, No. of branches/ plant of 11.33 and 12.08, weight of the main head 9.85 and $11.16 \mathrm{~g}, 1000$-grain weight of 2.65 and $2.78 \mathrm{~g}$ grain yield /plantof 12.43 and $13.95 \mathrm{~g}$, grain yield /fed of 556 and $622 \mathrm{Kg} / \mathrm{fed}$, and net return of 1,395 and 1,560 LE/fed. in first and second seasons.

Moisture, ether extract, crude protein, crude fiber, ash and carbohydrates contents of quinoa were 9.61, $3.93,13.97,10.31,3.67$ and $68.12 \%$, respectively. In addition, quinoa grains had higher contents of most essential amino acids, especially lysine.Also, quinoa grains had higher contents of minerals especially $\mathrm{Zn}, \mathrm{Fe}$, $\mathrm{Mg}$ and Ca. Finally, Quinoa grains could be introduced in bakery products to improve its nutritional value. It is a good source of nutrientsespecially for children and also for people who suffer from celiac disease (allergy to gluten), as a gluten-free crop.
\end{abstract}

Keywords: Quinoa, sowing dates, chemical composition, sandy soils.

\section{Introduction}

Quinoa (Chenopodium quinoaWilld.) is a very important cultivated food crop in the Peruvian and Bolivian Andes for more than 5000 years. It recently attracts attention because of its high nutritional value and strong growth potential under the extreme harsh conditions of drought and soil salinity. Apart from the high protein content, the grains are also rich in amino acids, minerals and vitamins which, meet or exceed thehuman requirements. The crop has been selected by the FAO (2003) as one of the main crops to play a major role in assuring food security in the $21^{\text {st }}$ century because of its high nutritional value and extreme resistance to adverse climatic conditions(FAO, 2011).

Quinoa is the only food crop that contains all the essential amino acids, trace elements and vitamins, and is also gluten-free. Although not a cereal, it is consumed in a similar way to rice and other staple grains. Quinoa also has a high content of all important minerals than maize, rice or wheat (except sodium), and contains large amounts of folate. It is also richer in protein and mono-saturated fatty acids(FAO, 2013).

Quinoa the newly introduced food crop can replenish part of food gap, since; the crop is drought and saline tolerant and can grow in sandy soil of arid and semiarid regions and with other most harmful abiotic adverse factors that affect crop production. Also quinoa would provide bread and other products for people who suffer from malnutrition, where quinoa is a highly nutritious food crop, with an outstanding protein quality and a high content of a range of vitamins and essential minerals (Jacobsen 2003, Jacobsen et al, 2003, Ogungbenle, 2003 and Shams, 2010 and 2012). Quinoa has enormous potential in the food industry being gluten-free and highly nutritious and suits marginal soils in environments with low rainfall. Hence, quinoa is recommended also as a useful staple food in food industries for baby food formulations (Ogungbenle, 2003). Quinoa has been selected by FAO as one of the crops destined to offer food security in the next century (FAO, 1998; Jacobsen 2003; Jacobsen et al, 2003 and Shams, 2010 and 2012) and ideal candidate crop for NASA Controlled Ecological Life Support System (CELSS) (NASA, 1993). The grains have not been found to contain anti-nutritional factors.

Quinoa grains can be used as a replacement of cereals and have an application in certain diets, because they do not contain gluten (Caperutoet al., 2000). 
Quinoa grains have high quality proteins and higher levels of energy, calcium, phosphorus, magnesium, iron, fiber, and B-vitamins than barley, oats, rice, corn, or wheat (Prakash and Pal, 1998; Oshodiet al., 1999; Dini et al. 2005 and Comaiet al., 2007). Quinoa grain lipids appear to be a high quality edible vegetable oil, similar in the fatty-acid composition to soybean oil (Comaiet al., 2007).

Quinoa proteins may be one of the more promising food ingredients, capable of complementing cereal or legume proteins, and there is the potential for the production of protein concentrates from dehulled quinoa grains, which could be used as raw materials in the food industry (Brinegaret al.,1996). Quinoa grain proteins are rich in amino acids like lysine, threonine and methionine that are deficient in cereals (Fleming and Galwey, 1995; Jacobsen, 2003 and 2011). Furthermore, FAO/WHO (1990) stated that the quality of quinoa is equal to the quality of protein of whole dried milk.

The Food and Agriculture Organization (FAO, 1990) observed that quinoa grains have high quality proteins and higher levels of energy, calcium, phosphorus, iron, fiber and B-vitamins than barley, oats, rice, corn or wheat (Koziol, 1992).

Quinoa grain is used to make different food products including bread, biscuits, cookies, crepes, muffins, pancakes, and tortillas. More recently, attention has been given to quinoa for people suffering celiac disease (allergy to gluten), as an alternative to wheat, rye and barley, all of which contain gluten (Fleming and Galwey, 1995 and Jacobsen, 2003 and 2011).

Quinoa flour can be mixed with maize or wheat flour. Several levels of quinoa flour substitution have been reported, for instance, in bread (10-13\% quinoa flour), noodles and pasta (30-40\% quinoa flour), and sweet biscuits (60\% quinoa flour) (ValenciaChamorro 2003 and Bharagavaet al., 2006).

Sowing is one of the most important activities of quinoa cropping because the emergence of seedlings impacts plant density and final yield. Seeds are sown, depending on location, variety, soil moisture and sowing depth (FAO, 2011).

In recent years, the cultivation of quinoa has gained rising attention. This study was undertaken to explore the best sowing date for Quinoa CV Titicacaand analyze its grain composition.

\section{Materials and Methods}

Field trial was carried out in Ismailia Agricultural Research Station, Agricultural Research Center, Egypt during 2010/2011 and 2011/2012 winter seasons to study the response of Quinoa CV Titicaca to three sowing dates i.e., $15^{\text {th }}$ of November, $1^{\text {st }}$ of December and $15^{\text {th }}$ of December under sandy soil using sprinkler irrigation system.

Data were recorded The experiment included three sowing dates $\left(15^{\text {th }}\right.$ of November, $1^{\text {st }}$ of
December and $15^{\text {th }}$ of December) to study their effects on plant height $(\mathrm{cm})$, No. of branches/ plant, weight of the main head $(\mathrm{g}), 1000$-grain weight $(\mathrm{g})$, grain yield /plant $(\mathrm{g})$, grain yield /fed $(\mathrm{Kg})$,total income LE/fed, total costs LE/fed and net return LE/fed. The randomized complete block design (RCBD) with four replications was used. The area of each plot was $24 \mathrm{~m}^{2}, 6 \mathrm{~m}$ in width $(15$ lines $40 \mathrm{~cm}$ apart) and $4 \mathrm{~m}$ in length.

Quinoa was grown in hills spaced $20 \mathrm{~cm}$ apart then thinned to one plant per hill. Plots were kept free of weeds through hand hoeing twice. Other cultural practices were performed as recommended. Harvesting of quinoa was after 120 days from planting.

The experimental field was finely prepared and calcium super phosphate $\left(\begin{array}{lll}15.5 \% & \mathrm{P}_{2} \mathrm{O}_{5}\end{array}\right)$ was applied during soil preparation at the rate of $15.5 \mathrm{Kg}$ $\mathrm{P}_{2} \mathrm{O}_{5} / \mathrm{fed}$. Nitrogen in the form of ammonium nitrate $(33.5 \% \mathrm{~N})$ was applied at the rate of $90 \mathrm{Kg} \mathrm{N} /$ fed.in four equal doses, the first after four weeks from planting date and the other doses every two weeks.

\section{Data recorded:}

Samples were taken after 110 days from seeding date and consisted of ten plants taken at random from the two inner ridges of each plot to determine plant height $(\mathrm{cm})$ and No. of branches/ plant, while other yield traits i.e., weight of the main head $(\mathrm{g}), 1000$ grain weight $(\mathrm{g})$, Grain yield /plant $(\mathrm{g})$ were determined at harvest except for the grain yield /fed. $(\mathrm{Kg})$ trait which was on plot basis in both seasons.

\section{Chemical composition:}

Grain samplesfrom each replicate of best grain yield treatment were taken in the second season after harvesting and mixed together, left for air drying to $15 \%$ moisture content and sent to laboratory for chemical analysis.

Moisture, crude protein, crude fat, ash and crude fiber of quinoa were determined according to AOAC (2005).

Minerals content of quinoa (magnesium, sodium, zinc, manganese, iron, calcium, potassium and cupper) were determined using a pyeunicumSp 1900 Atomic absorption spectroscopy technique after dry ashing according to the method described in AOAC (2005). Amino acids content of quinoa was determined according to the method described by Pellet and Young (1980).

\section{Statistical analysis:}

Data were analyzed using ANOVA in Randomized Complete Block Design (RCBD) with four replications. MSTAT-C (1988) was used for statistical computations. 
Soil analysis:

Soil samples from each plot were taken from 0 $30 \mathrm{~cm}$ depth before planting quinoa mixed together and sent to laboratory for mechanical and chemical analysis in the first and second seasons, respectively. Data are presented in Table (1).

Table 1. Soil mechanical and chemical analysis (Average of two seasons).

\begin{tabular}{|c|c|c|c|c|c|c|}
\hline & & Silt $(\%)$ & & Sand $(\%)$ & \multicolumn{2}{|c|}{ SoilTexture } \\
\hline & & $\mathbf{0}$ & & 91.36 & \multicolumn{2}{|c|}{ Sandy } \\
\hline \multirow[b]{2}{*}{ pH } & \multirow[b]{2}{*}{$\mathrm{EC}(\mathrm{dS} / \mathrm{m})$} & \multirow[b]{2}{*}{ OM\% } & \multirow[b]{2}{*}{$\mathrm{CaCO}_{3}(\%)$} & \multicolumn{3}{|c|}{ Macro nutrient } \\
\hline & & & & $\begin{array}{c}\mathrm{N} \\
(\mathrm{mg} / \mathrm{Kg})\end{array}$ & $\begin{array}{c}\mathbf{P} \\
(\mathrm{mg} / \mathrm{Kg})\end{array}$ & $\begin{array}{c}\mathrm{K} \\
(\mathrm{mg} / \mathrm{Kg})\end{array}$ \\
\hline 8.45 & 0.20 & 0.15 & 0.64 & 10 & 18 & 84 \\
\hline \multicolumn{4}{|c|}{ Soluble cations (meq/L) } & \multicolumn{3}{|c|}{ Soluble anions (meq/L) } \\
\hline $\mathbf{K}^{+}$ & $\mathbf{N a}^{+}$ & $\mathbf{M g}^{++}$ & $\mathrm{Ca}^{++}$ & $\mathrm{Cl}^{-}$ & $\mathrm{HCO}_{3}$ & $\mathrm{CO}_{3}^{--}$ \\
\hline 0.09 & 0.7 & 0.9 & 0.9 & 0.78 & 0.45 & - \\
\hline
\end{tabular}

Data of air temperature of the experimental area are recorded in Table (2).

Table 2. Air temperature averages data of Ismailia during Quinoa growing season (Average of two seasons):

\begin{tabular}{lccc}
\hline Month & Max. Temp. $\left(C^{O}\right)$ & Min. Temp. $\left(C^{O}\right)$ & Temp. average \\
\hline November & 26.39 & 15.23 & 20.81 \\
December & 19.52 & 9.26 & 14.39 \\
January & 20.31 & 9.14 & 14.72 \\
February & 21.33 & 9.02 & 15.17 \\
March & 24.25 & 11.28 & 17.77 \\
April & 28.95 & 14.02 & 21.49 \\
\hline
\end{tabular}

\section{Results and Discussion}

\section{Agronomic evaluation}

Results in table (3) indicated that there were increases in values of plant height, No. of branches/ plant, weight of the main head, 1000-grain weight, grain yield /plant and grain yield /fed with delaying sowing date from $15^{\text {th }}$ of November till $15^{\text {th }}$ of December in both seasons. These results were in agreement withBajwa (2011) who tested four sowing dates of quinoa on 15 October, 15 November, 15 December and 15 January and reported 15 December as more appropriate date.

The increases in plant height and number of branches per plant traits were significant between first and second or first and third sowing dates, but without significant increases between second and third sowing dates, while the significant was among all sowing dates in case of plant height in the first season only. The increases in 1000-grain weight were insignificant among all sowing dates in both seasons.

The differences in case of weight of the main head per plant, grain yield per plant and grain yield per fed were insignificant between first and second or second and third sowing dates, while the significant differences occurred between first and third sowing dates, in both seasons. These results are in accordance with those obtained byJacobsen and Bach (1998) andHirichet al., (2014).

Table 3. Effect of sowing dates on Quinoa in 2010/2011 and 2011/2012 winter seasons.

\begin{tabular}{|c|c|c|c|c|c|c|}
\hline $\begin{array}{l}\text { Trait } \\
\text { Sowing } \\
\text { date }\end{array}$ & $\begin{array}{l}\text { Plant height } \\
(\mathrm{cm})\end{array}$ & $\begin{array}{l}\text { No. of } \\
\text { branches/ } \\
\text { plant }\end{array}$ & $\begin{array}{l}\text { Weight of the } \\
\text { main head } \\
(\mathrm{g})\end{array}$ & $\begin{array}{l}\text { 1000-grain } \\
\text { weight } \\
(\mathrm{g})\end{array}$ & $\begin{array}{c}\text { Grain yield } \\
\text { plant } \\
(\mathrm{g})\end{array}$ & $\begin{array}{c}\text { Grain } \\
\text { yield/fed }(\mathrm{Kg})\end{array}$ \\
\hline & \multicolumn{6}{|c|}{$2010 / 2011$} \\
\hline $15^{\text {th }}$ Nov. & $42.90 \mathrm{c}$ & $8.98 b$ & $7.49 \mathrm{~b}$ & $2.18 \mathrm{a}$ & $9.33 \mathrm{~b}$ & $433 \mathrm{~b}$ \\
\hline $1^{\text {st }}$ Dec. & $52.55 b$ & $10.71 \mathrm{a}$ & $8.70 \mathrm{ab}$ & $2.45 \mathrm{a}$ & $11.08 \mathrm{ab}$ & $497 \mathrm{ab}$ \\
\hline \multirow[t]{2}{*}{$15^{\text {th }}$ Dec. } & $57.73 \mathrm{a}$ & $11.33 \mathrm{a}$ & $9.85 \mathrm{a}$ & $2.65 \mathrm{a}$ & $12.43 \mathrm{a}$ & $556 \mathrm{a}$ \\
\hline & \multicolumn{6}{|c|}{$2011 / 2012$} \\
\hline $15^{\text {th }}$ Nov. & $48.35 \mathrm{~b}$ & $9.50 \mathrm{~b}$ & $8.72 \mathrm{~b}$ & $2.20 \mathrm{a}$ & $9.55 \mathrm{~b}$ & $467 \mathrm{~b}$ \\
\hline $1^{\text {st }}$ Dec. & $57.05 \mathrm{a}$ & $11.21 \mathrm{a}$ & $10.40 \mathrm{ab}$ & $2.50 \mathrm{a}$ & $11.98 \mathrm{ab}$ & $542 \mathrm{ab}$ \\
\hline $15^{\text {th }}$ Dec. & $61.50 \mathrm{a}$ & $12.08 \mathrm{a}$ & $11.16 \mathrm{a}$ & $2.78 \mathrm{a}$ & $13.95 \mathrm{a}$ & $622 a$ \\
\hline
\end{tabular}



Chemical composition of quinoa grains.

Results in Table (4) revealed that quinoa grains contained high amounts of crude protein, crude fiber, ash and carbohydrates $(13.97,10.31,3.67$ and $68.12 \%$, respectively). Results are in agreement withDeBruin (1964)andLamenca (1979) who reported that chemical composition of quinoa ranged from 10 to $18 \%, 4.50$ to $8.75 \%, 2.40$ to $3.65 \%$ and 2.10 to $4.90 \%$, for protein, crude fat, ash and crude fiber, respectively. Koziol (1992) reported that quinoa contains $14.60 \%$ protein (on fresh weight). Bharagavaet al., (2006) showed that, the ash content of quinoa $(3.4 \%)$, is higher than that of rice $(0.5 \%)$, wheat $(1.8 \%)$ and other traditional cereals. The chemical composition of quinoa grains varied from 8 to $22 \%, 2$ to $10 \%$ and 67 to $74 \%$ for protein, fats and carbohydrates, respectively (Valencia-Chamorro, 2003).

Jancurováet al. (2009) mentioned that quinoa grains contain $16.50 \%$ protein, $6.30 \%$ fat, $3.8 \%$ fiber, $3.8 \%$ ash and $69 \%$ carbohydrates which is higher on average than that in common cereals such as rice, wheat, and barley.

Table 4. Chemical composition of quinoa grains.

\begin{tabular}{cccccc}
\hline Moisture & Ether extract & Crude protein & Crude fiber & Ash & Carbohydrates* \\
\hline 9.61 & 3.93 & 13.97 & 10.31 & 3.67 & 68.12 \\
\hline
\end{tabular}

*Total carbohydrate was calculated by differences.

\section{Minerals content}

Table (5) shows minerals content of quinoa grains. Data revealed that all minerals were higher in quinoa than those found in other cerealsFAO/WHO (1990). These results indicated that the content of $\mathrm{Mg}, \mathrm{Na}, \mathrm{Mn}$ and $\mathrm{K}$ in quinoa was higher than those found inwheat. While, the content of $\mathrm{Zn}, \mathrm{Fe}$ and $\mathrm{Cu}$ in quinoa was about five times higherthan those found in wheat flour. Furthermore, the content of $\mathrm{Ca}$ in quinoa wasabout three times higherthan those found in wheat flour. These results are in agreement with those obtained by Koziol (1992)and Hareedyet al., (2009). Bharagavaet al., (2006) mentioned that quinoa grains contain large amounts of minerals like $\mathrm{Ca}, \mathrm{Fe}, \mathrm{Zn}, \mathrm{Cu}$ and $\mathrm{Mn}$. Calcium and iron are significantly higher than most commonly used cereals. Ruales and Nair (1992) reported large amounts of iron $(81 \mathrm{ppm})$ and calcium $(874 \mathrm{ppm})$ in quinoa. It has about $0.26 \%$ for magnesium in comparison with $0.16 \%$ for wheat and $0.14 \%$ for corn.

Quinoa grains are rich in micronutrients such as minerals and vitamins. The main minerals are potassium, phosphorus and magnesium. According to the National Academy of Sciences (2004) the magnesium, manganese, copper and iron present in quinoa grains covers the daily needs of infants and adults, while phosphorus and zinc is sufficient for children, but covers 40 to $60 \%$ of the daily needs of adults. The potassium content can contribute between $18 \%$ and $22 \%$ of infant and adult requirements, while the calcium content can contribute $10 \%$ of the requirements (James, 2009).

Ruales and Nair (1993) found that quinoa contains larger amounts of calcium (874 ppm), magnesium (26 ppm), iron (81 ppm), zinc (36 ppm) and copper (10 ppm) than most of the common cereal grains.

Table 5. Minerals content of quinoa grains (ppm).

\begin{tabular}{|c|c|c|c|c|c|c|c|}
\hline Mg & $\mathbf{N a}$ & $\mathbf{K}$ & $\mathbf{C a}$ & $\mathbf{F e}$ & $\mathbf{Z n}$ & Mn & $\mathbf{C u}$ \\
\hline 58.70 & 151.90 & 170.10 & 81.60 & 149.10 & 61.10 & 17.30 & 5.65 \\
\hline
\end{tabular}

\section{Amino acids content}

Results in Table (6) showed that quinoa grains contained high amount of essential amino acids except for isoleucine, leucine and phenylalanine. In addition, quinoa grain contained high amount of aspartic, alanine, glycine, arginine, histidine and total non-essential amino acids percentage $(27.54 \mathrm{~g} / 100 \mathrm{~g}$ protein). These results are in agreement with those obtained by Hareedyet al. (2009). Moreover, James (2009) reported that quinoa proteins have higher histidine content than barley, soy, or wheat proteins.

Koziol (1992) found that quinoa was rich in histidine and lysine (3.20 and $6.10 \%$ of protein composition, respectively). Moreover, the amount of lysine and sulfur amino acids (methionine + cystine) was relatively high. In general, the content of essential amino acids in quinoa is higher than in common cereals (Ruales and Nair, 1992). Amino acid analysis showed that quinoa is an excellent source of lysine, methionine, cystine in addition to other essential amino acids, and it meets or exceeds the recommendations for proper amino acid nutrition (Abugochet al., 2009).

\section{Economic evaluation}

Data in table (7) indicated clearly that there were increases in values of total income, total costs and net return traits with delaying sowing date from $15^{\text {th }}$ of November to $15^{\text {th }}$ of December in both seasons. 
Table 6. Amino acids content of quinoa grains.

\begin{tabular}{lclc}
\hline $\begin{array}{l}\text { Essential } \\
\text { amino acids }\end{array}$ & g/100g protein & $\begin{array}{c}\text { Non-essential } \\
\text { amino acids }\end{array}$ & g/100g protein \\
\hline Lysine & 4.58 & Glutamic & 13.15 \\
Methionine+ Cystine & 2.41 & Aspartic & 6.78 \\
Isoleucine & 2.83 & Proline & 4.28 \\
Leucine & 4.98 & Alanine & 3.04 \\
Phenylalanine & 3.10 & Glycine & 4.35 \\
Tyrosine & 2.81 & Serine & 3.18 \\
Threonine & 2.72 & Arginine & 9.21 \\
Valine & 4.11 & Histidine & 3.11 \\
Total essential amino & 27.54 & Total non-essential & 47.10 \\
acids & & aminoacids & \\
\hline
\end{tabular}

Table 7. Effect of sowing dates on total income, total costs and net return (LE /fed) in 2010/2011 and 2011/2012 winter seasons.

\begin{tabular}{|c|c|c|c|}
\hline $\begin{array}{l}\text { Trait } \\
\text { Sowing date }\end{array}$ & $\begin{array}{l}\text { Total income } \uparrow / \text { fed } \\
\text { (LE) }\end{array}$ & $\begin{array}{c}\text { Total costs } \$ \text { /fed } \\
\text { (LE) }\end{array}$ & $\begin{array}{l}\text { Net return /fed } \\
(\text { LE) }\end{array}$ \\
\hline & \multicolumn{3}{|c|}{$2010 / 2011$} \\
\hline $15^{\text {th }}$ Nov. & 4,550 & 3,464 & 1,086 \\
\hline $1^{\text {st }}$ Dec. & 5,223 & 3,976 & 1,247 \\
\hline $15^{\text {th }}$ Dec. & 5,843 & 4,448 & 1,395 \\
\hline & \multicolumn{3}{|c|}{$2011 / 2012$} \\
\hline $15^{\text {th }}$ Nov. & 4,907 & 3,736 & 1,171 \\
\hline $1^{\text {st }}$ Dec. & 5,695 & 4,336 & 1,359 \\
\hline $15^{\text {th }}$ Dec. & 6,536 & 4,976 & 1,560 \\
\hline
\end{tabular}

$†$ Price of quinoa grains (US\$ 1,469.70/ton = LE 10,508 /ton), source FAOStat data, 2014.

+ A kilo cost approximately US\$ $1.15=\mathrm{LE} \mathrm{8/Kg}$, World Bank, 2014.

The increases in net return of the second and third dates over the first date were 14.83 and $28.45 \%$ in the first season and 16.05 and $33.22 \%$ in the second season, respectively. These results are in agreement with those recorded by Jacobsen (2003), who reported thatthe economic result for the farmer depends on the yield and the price to be achieved for the cropand add that any improved result will be obtained with either an increased yield or a higher price. Shams (2012) found that quinoa can be grown under harsh conditions of sandy soils, arid environment and limited irrigation water of $1850 \mathrm{~m}^{3}$ /fed with acceptable.

\section{Conclusion}

Onthe basis of the results presented here, we may conclude that quinoa can be planted in sandy soils from the $1^{\text {st }}$ to $15^{\text {th }}$ of December (the first half) without significant loses in grain yield. However, more research is needed to fit this crop in the crop rotations prevailing in areas with abiotic stresses.

Quinoa grains is an excellent contribution to the diet according to its protein content and amino acid composition. Quinoa grains had high contents of most essential amino acids, especially lysine. Also, quinoa grains had high contents of minerals especially $\mathrm{Zn}, \mathrm{Fe}, \mathrm{Mg}$ and $\mathrm{Ca}$. Finally, quinoa grainscould be introduced in bakery products to improve its nutritional value in which, it is a good source of nutrient especially for children and people who suffer from celiac disease (allergy to gluten).

\section{References}

Abugoch, L.; E. Castro; C. Tapia; M.C. Añón; P. Gajardo and A. Villarroel (2009). Stability of quinoa flour proteins (Chenopodium quinoaWilld.) during storage. Inter. J. Food Sci. Tech., 44: 2013-2020.

AOAC (2005). Association of Official of Analytical Chemists, Official Methods of Analysis. $18^{\text {th }}$ Ed., Washington DC, USA.

Bajwa, H.M. (2011). Introduction and assessment of quinoa (Chenopodium quinoaWilld) as a potential climate proof grain crop. $\mathrm{PhD}$ thesis, Univ. Agric., Faisalabad, Pakistan.

Bharagava, A.; S. Shukla and D. Ohri (2006).Chenopodium quinoa- An Indian perspective. Industrial Crops products. 23:7387.

Brinegar, C.; B. Sine, and L. Nwokocha (1996). High-Cysteine $2 \mathrm{~S}$ seed storage proteins from quinoa (Chenopodium quinoa). J. Agric. Food Chem., 44:1621-1623. 
Caperuto, L.; J. Amaya-Farfan and C. Camargo (2000). Performance of quinoa (ChenopodiumquinoaWilld.) flour in the manufacture of gluten-free spaghetti. Food Agri., 8: 95-101.

Comai, S.; A. Bertazzo; L. Bailoni; M. Zancato; C. Costaand G. Allegri (2007). The content of proteic and nonproteic (free and protein-bound) tryptophan in quinoa and cereal flours. Food Chem., 100: 1350-1355.

DeBruin, A. (1964). Investigation of the food value of quinoa and canihue seed. J. Food. Sci., 29: 872-876.

Dini, I.; G.C. Tenore and A. Dini (2005). Nutritional and antinutritional composition of Kancolla seeds: an interesting and underexploited andine food plant. Food Chem., 92: $125-132$.

FAO/WHO (1990). Protein quality evaluation in Report of Joint FAO/WHO expert consultation; Food and Agricultural Organization of the United Nations: Rome, 23.

FAO (1998). Under-Utilized Andean Food Crops. Rome, Italy.

FAO (2003). The State of Food Insecurity in the World. Published by the Food and Agriculture Organization of the United Nations VialedelleTerme di Caracalla, 00100 Rome, Italy.

FAO (2011). Quinoa: An ancient crop to contribute to world food security. Vitacura, Santiago de Chile.

FAO (2013). Food outlook: Biannual report on global food markets.

FAO (2014). FAOStat data. http://faostat.fao.org

Fleming, J. E. and N.W. Galwey (1995). Quinoa (Chenopodium quinoa Willd). In: Williams, J. T. (Eds), Cereals and Pseudocereals. Champman and Hall-London, pp.3-83.

Hareedy, L. A. M.; A.M. Mahafauz and A.S. Kamel (2009). Soybean-quinoa drinks from newly introduced quinoa varieties in Egypt. Egyptian J. Nutr., XXIIII (1): 125-160.

Hirich, A.; R. Choukr-Allah and S.-E. Jacobsen (2014). Quinoa in Morocco - Effect of Sowing Dates on Development and Yield. J. Agron. Crop Sci., 200 (5): 371-377.

Jacobsen, S.E. (2003). The Worldwide Potential for Quinoa (ChenopodiumquinoaWilld.). Food Reviews International, 19(1): 167-177.

Jacobsen, S.E. (2011). The situation for quinoa and its production in Southern Bolivila: from Economic Success to Environmental Disaster. J. Agronomy Crop Sci., 10:1439.

Jacobsen, S.E., and A. Bach (1998). The influence of temperature on seed germination rate in quinoa (ChenopodiumquinoaWilld.). Seed Sci. Technol. 26, 515-523.

Jacobsen, S.E.; A. Mujica and C.R. Jensen (2003). The resistance of quinoa
(ChenopodiumquinoaWilld.) to adverse, abiotic factors. Food Reviews International 19: 99109.

James, L.E.A. (2009). Quinoa (ChenopodiumquinoaWilld.): composition, chemistry, nutritional, and functional properties. Advances Food Nutr. Research, 58: $1-31$.

Jancurová M.; L.Minarovičová and A.Dandár (2009). Quinoa - a review. Czech J. Food Sci., 27: 71-79.

Koziol, M.J. (1992). Chemical composition and nutritional evaluation of quinoa (ChenopodiumquinoaWilld.). Journal of Food Composition and Analysis, 5, 36-68.

Lamenca, M.B. (1979). Composicion de la quinoa cultivada en el altiplano de Puno, Perv. Turrialba, 29: 219.

MSTAT-C (1988). A micro-computer program for the design, management, and analysis of agronomic research experiments. Michigan State Univ., East Lansing, MI.

NASA (1993).Quinoa: An emerging new crop with potential for CELSS. NASA Technical Paper 3422.

National Academy of Sciences (2004). Comprehensive DRI table for vitamins, minerals and macronutrients, organized by age and gender. Institute of Medicine. Food and Nutrition Board, Beltsville, MD.

Ogungbenle, H.N.(2003). Nutritional evaluation and functional properties of quinoa (ChenopodiumquinoaWilld.) flour. International Journal of Food Sciences and Nutrition 54, $153-158$.

Oshodi, A.A.; H.N.Ogungbenleand M.O. Oladimeji (1999). Chemical composition, nutritionally valuable minerals and functional properties of benniseed (Sesamumradiatum), pearl millet (Pennisetumtyphoides) and quinoa (Chenopodium quinoa) flours. Int. J. Food Sci. Nutr., 50: 325-331.

Pellet, P.L. and V.R. Young (1980). Nutritional evaluation of protein foods, Report of a working group sponsored by the International Union of Nutritional Sciences and the United Nations University World Hunger Programme. The United Nations University.

Prakash, D. and M. Pal (1998). Chenopodium: Seed protein, fractionation and amino acid composition. Int. J. Food Sci. Nutr., 49: 271275.

Ruales, J. and B.M. Nair (1992). Nutritional quality of the protein in quinoa (Chenopodium quinoa, Willd) seeds. Plant Foods Human Nutr., 42(1): $1-11$.

Ruales, J. and B.M. Nair (1993). Content of fat, vitamins and minerals in quinoa (Chenopodium quinoa, Willd) seeds. Food Chem., 48: 131136. 
Shams, A.S. (2010). Combat degradation in rainfed areas by introducing new drought tolerant crops in Egypt. $4^{\text {th }}$ International Conference on Water Resources and Arid Environments, Riyadh, Saudi Arabia, 5- 8 December, 575-582.

Shams, A.S. (2012). Response of quinoa to nitrogen fertilizer rates under sandy soil conditions. Proc. $13^{\text {th }}$ International Conf.
Agron.,Fac.ofAgic., Benha Univ., Egypt, 9-10 September.

Valencia-Chamorro, S. A (2003). Quinoa. In: Caballero B.: Encyclopedia of Food Science and Nutrition. Academic Press, Amsterdam, Vol. 8: pp. 4895-4902.

World Bank (2014). http://www.worldbank.org 


\section{تأثير مواعيد الزراعة على حبوب الكينوا و التركيب الكيماوى}

عمرو سعد شمس1 1 ، وفاء كمال جلال 2

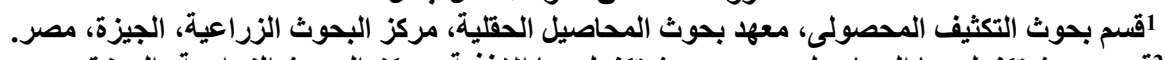

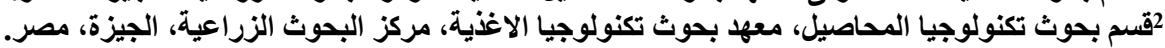

تعد زراعـة المحاصبل الحقليـة فى البيئة القاحلـة والأراضـى الرمليـة مـن أكبر التهديدات التى تواجـه الأمسن الغذائى وخاصـة لدى صـغار

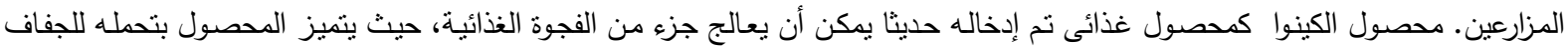

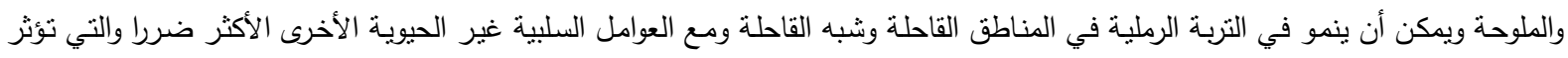
على إنتاج المحاصيل.

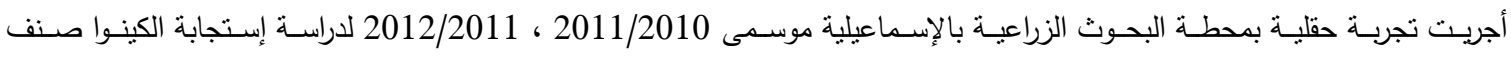
(Titicaca) لمواعيد الزراعـة (15 نوفمبر ، 1 ديسمبر ، 15 ديسمبر ) تحت ظروف الأراضى الرملية والرى بـالرش مـع تحليل الحبوب الناتجـه لتقييم فوائد المحصول.

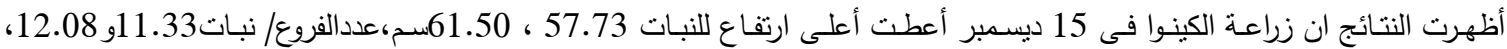

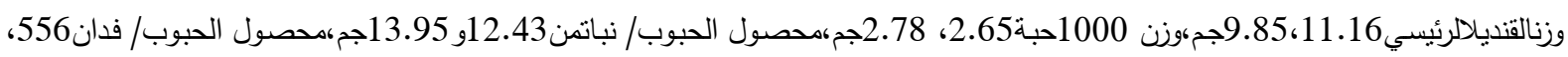

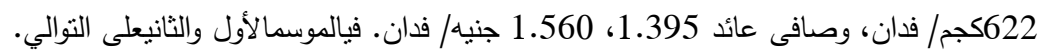

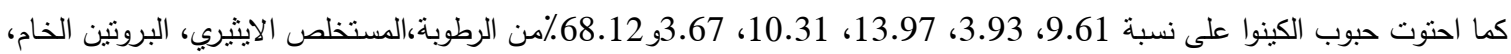

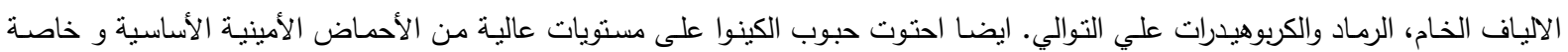

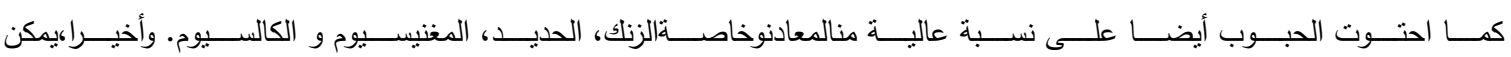

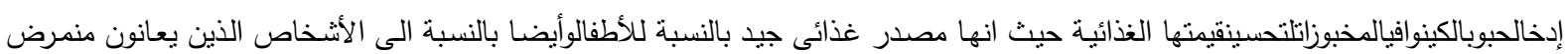
الاضطرابات الهضمية(حساسية الجلوتين)، كمحصول خالى من الجلوتين.

الكلمات الكثافة : الكينوا ، مواعيد الزراعة ، التركيب الكيماوى ، الأراضى الرملية . 